\title{
PROCESS-ORIENTED INQUIRY LEARNING ENHANCES STUDENTS' CRITICAL THINKING SKILLS
}

\author{
Nurussaniah", Ira Nofita Sari \\ Departement of Physics Education, IKIP PGRI Pontianak \\ *Email: nurussaniah@gmail.com
}

Diterima: 20 Juni 2019. Disetujui: 24 September 20019. Dipublikasikan: 30 September 2019

\begin{abstract}
The objective of this study is to determine the applied inquiry learning to improve the students' critical thinking skills. This study uses non-equivalent control group design. Students in this study were divided into two class activities. The experimental class was treated with the application of inquiry learning, while the control class was given the conventional learning. In this study, the students' critical thinking skill is obtained through a test. The test used was a critical thinking skill test consisting of five questions with the following indicators, namely: completing information, finding and defining problems, recognizing assumptions and formulating hypothesis. The result shows that the gain value in the experimental class is higher than the gain value in the control class. It indicates that the improvement of students' critical thinking skills in the experimental class is higher than the students' critical thinking skills in the control class. Therefore, it can be said that the application of inquiry learning provides a more significant improvement than conventional learning. The students' critical thinking skills show an increase at the medium category on the aspect of completing information, recognizing assumption and formulating hypothesis. Meanwhile, on aspect of finding and defining problem, students' critical thinking skills show an increase at the low category or it can also be said it does not show any increase.
\end{abstract}

Keywords : Skill Critical thinking skills, Inquiry Learning

\section{INTRODUCTION}

Physics is one of Natural Science (IPA) branches. Physics is the study of the structure of matter and its interaction in order to understand the natural systems and artificial/technological systems [1]. It is fundamental that Physics as part of IPA must be studied. The nature of science (Physics included) comprises of the four main elements, namely: attitude, processes, products and applications.

Learning physics will be more meaningful if learners are actively involved in learning activities. The significances of learning physics are in the processes of observing, understanding and exploiting the natural phenomena that exist in the surrounding environment [2]. In addition, the learning process of physics emphasizes the provision of direct experience to develop competence to explore and understand the natural surroundings scientifically and implement it in scientific inquiry to improve the ability to think, work and be scientific and communicate it as an important aspect of life skills [3]. Therefore, in learning physics, process is the emphasis of learning. Therefore, the learners do not merely need to master the concept of memorization but they also need to be able to apply the concept they have on other aspects. It can be improved through process skills and critical thinking skills.

Scientific process skills are fundamental to problem solving in science and scientific methods [4]. By mastering scientific process skill, learners will easily understand the complex and abstract concepts through concrete explanations. In addition, critical thinking skill is an active intellectual process and ability in making sense or concept, apply, analyze, synthesis and evaluate. Therefore, the scientific process and critical thinking skills are the life skills that must be possessed by learners.

The objectives of learning physics can be realized with the application of quality learning of physics. Quality learning is an effective learning where learners play an active role in the learning processes. One of the learning components that affect student learning outcomes is teacher. Creative and professional teachers are able to make the learning atmosphere more effective and enjoyable. Inquiry learning emphasizes the thought process of finding and finding answers to a problem. Besides, inquiry approach is based on a concept of learning where the teacher is the only one who provides knowledge to the student; instead, learners must build their own knowledge in their minds [5]. Referring to this, it can be seen that the inquiry model can support the critical thinking skill as an effort to equip learners to gain a better understanding of the concept. Therefore, this study will apply an inquiry learning to improve the critical thinking skills of students in Physics Education Study Program of IKIP-PGRI Pontianak.

\section{RESEARCH METHOD}

This study uses non-equivalent control group design [6]. The design of this study is presented in Table 1.

Table 1. Design of the study

\begin{tabular}{cccc}
\hline Class & Pretest & Treatment & Posttest \\
\hline Experiment & $\mathrm{O}_{1}$ & Inquiry learning & $\mathrm{O}_{2}$ \\
Control & $\mathrm{O}_{3}$ & - & $\mathrm{O}_{4}$ \\
\hline
\end{tabular}


From Table 1, it is known that $\mathrm{O} 1$ and $\mathrm{O} 2$ are pretest and posttest of the experimental class. While $\mathrm{O} 3$ and $\mathrm{O} 4$ are pretest and posttest of the control class. Pretest and posttest are administered to find out the critical thinking skills before and after the inquiry learning is applied. In addition, it is important to note that the application of inquiry learning in this study is carried out on the subject of dynamic electricity.

Students in this study were divided into of two class activities (see Table 1). The experimental class was treated with the application of inquiry learning by taking these steps, namely: orientation, solving the problem, formulating hypotheses, collecting data, testing hypotheses, and drawing conclusions [7]. Meanwhile, the control class was treated with the conventional approach for their learning activities. The population in this study were students of Physics Education Program of IKIP PGRI Pontianak consisting of 1 class of Semester II, 2 classes of Semester IV and 3 class of Semester VI. The entire population was given a pretest to determine the initial critical thinking skills. The result of Barlett test analysis to the pretest value of the population shows that there were only three homogeneous classes, namely: class A Morning and class A afternoon of Semester IV and class A afternoon of Semester VI. Therefore, the samples of this study were class A morning and class A afternoon of Semester IV determined through purposive sampling technique. The sample selection took into account the same academic level in the Semester IV. Meanwhile, the experimental class is class A morning and the control class is class A afternoon.

Table 2. The categories of critical thinking skills

\begin{tabular}{cc}
\hline $\mathrm{x}$ & Categories \\
\hline $81.25<\mathrm{x} \leq 100$ & Very critical \\
$62.50<\mathrm{x} \leq 81.25$ & Critical \\
$43.75<\mathrm{x} \leq 62.50$ & Less critical \\
$25.00<\mathrm{x} \leq 43.75$ & Very less critical \\
\hline
\end{tabular}

In this study, the students' critical thinking skill was obtained through a test. The test used was a critical thinking skill test consisting of five questions with the following indicators, namely: completing information, finding and defining problems, recognizing assumptions and formulating hypothesis [8] [9]. In addition, the test has been validated and concluded feasible by three validators. Data of critical thinking skills were analyzed using percentages. Students' critical thinking skills can be divided into four categories as seen in Table 2 [10].

Furthermore, to know the improvement of students' critical thinking skill after the application of inquiry learning, the results of the test were analyzed with the normalized gain based on Hake's theory. It can be seen that $g$ is a normalized gain value which is then interpreted to indicate an increase in the student's critical thinking skill. The normalized gain criteria can be seen in Table 3 .

Table 3. The normalized gain criteria

\begin{tabular}{cc}
\hline$g$ & Interpretation \\
\hline $0.7<\mathrm{g}<1$ & High \\
$0.3<\mathrm{g}<0.7$ & Medium \\
$0<\mathrm{g}<0.3$ & Low \\
\hline
\end{tabular}

\section{RESULT AND DISCUSSION}

The results of this study show that the application of inquiry learning can improve student's critical thinking skills. This result can be seen in the Table 4.

Table 4. Gain (g) of student's critical thinking skills

\begin{tabular}{lllll}
\hline & pretest & posttest & $\mathrm{g}$ & Interpretation \\
\hline $\begin{array}{l}\text { Experiment } \\
\text { class }\end{array}$ & 21.43 & 49.11 & 0.35 & Medium \\
$\begin{array}{l}\text { Control class } \\
15.97\end{array}$ & 39.29 & 0.28 & Low \\
\hline
\end{tabular}

Table 4 shows that the gain value in the experimental class is higher than the gain value in the control class. It indicates that the improvement of students' critical thinking skills in the experimental class is higher than the students' critical thinking skills in the control class. Therefore, it can be said that the application of inquiry learning provides a more significant improvement than the conventional learning.

The students' critical thinking skills after taking the inquiry learning (experiment class) can be seen in Table 5. It can be seen that the students' critical thinking skills increase at the medium category on aspect of completing information, recognizing assumption and formulating hypothesis. Meanwhile, on the aspects of finding and defining problem, students' critical thinking skills increase at the low category or it can also be said it does not show any increase.

Table 5. Students' critical thinking skills

\begin{tabular}{lllllll}
\hline Students' critical thinking & Pretest & categories & posttest & Categories & $\mathrm{g}$ & Interpretation \\
\hline Completing information & 42.88 & Less critical & 64.29 & Critical & 0.38 & Medium \\
\hline $\begin{array}{l}\text { Finding and defining } \\
\text { problem }\end{array}$ & 14.29 & $\begin{array}{l}\text { Very less } \\
\text { critical }\end{array}$ & 28.57 & $\begin{array}{l}\text { Very less } \\
\text { critical }\end{array}$ & 0.17 & Low \\
\hline Recognizing assumption & 21.43 & $\begin{array}{l}\text { Very less } \\
\text { critical }\end{array}$ & 60.71 & Critical & 0.50 & Medium \\
\hline Formulating hypothesis & 7.14 & $\begin{array}{l}\text { Very less } \\
\text { critical }\end{array}$ & 42.86 & Less critical & 0.38 & Medium \\
\hline
\end{tabular}


The students' critical thinking skills are sharpened through inquiry learning by taking these steps, namely: orientation, solving the problem, formulating hypotheses, collecting data, testing hypotheses and drawing conclusions [7]. In the orientation, students were shown a video displaying the application of Ohm's Law in everyday life. The video showed that there is someone who cannot turn on a computer though the cable is plugged in. Furthermore, students were invited to find and define problems based on the video shown. The next step was solving the problem. In this step, students were invited to recognize the assumption based on a defined problem. Afterwards, students were invited to formulate hypotheses based on these assumptions through the third step, i.e. formulating hypotheses. The next steps were collecting data, testing hypotheses and drawing conclusions. These steps were through experimental activities used to train students' skill in completing information to answer problems and prove hypotheses. From these steps, it can be seen that the steps are able to train students to conduct scientific activities such as those conducted by scientists. Inquiry learning with experiments provides hands-on experience to students to discover and understand concept and improve their critical thinking skills. Guided experiment learning is more effective in improving students' critical thinking skills than the conventional learning [11]. In addition, Laboratory inquiry can improve the students' conceptual understanding and critical thinking skills. These results are in line with the research that has been done by [12] in which guided inquiry can improve the critical thinking skill, i.e. on the aspect of formulating hypothesis. Besides, another research also shows that the student worksheet developed with inquiry approach can optimize students' critical thinking skills [13].

In this study, there is one aspect of critical thinking skills showing very low increase, i.e. finding and defining problem. It indicates that the students have not been able find and define the problem of a concept presented through inquiry learning. Therefore, another learning model is needed to improve the ability to think critically on this aspect. One of the models that can be applied is problem-based learning. This is in line with research by Fakhriyah stating that the application of the problem-based learning can help students develop critical thinking skills on the aspects of identifying, analyzing, solving problems creatively, the ability to determine the right solution in solving problems, the ability to ask or criticize problems from other groups, the ability to answer questions and express opinions at the time of presentation appropriately based on appropriate learning resources [14]. As a result, another model that can be used to improve students' critical thinking skills is problem-based instruction [15]. Therefore, modification by combining more than one learning model can be used to improve students' critical thinking skills better. One modification of learning that can improve critical thinking skills is learning using e-learning [16].

\section{CONCLUSION}

The results show that the gain value in the experimental class is higher than the gain value in the control class. It indicates that the improvement of students' critical thinking skills in the experimental class is higher than the students' critical thinking skills in the control class. Therefore, it can be said that the application of inquiry learning provides a more significant improvement than the conventional learning. The students' critical thinking skills show increase at the medium category on aspect of completing information, recognizing assumption and formulating hypothesis. Meanwhile, on the aspects of finding and defining problem, students' critical thinking skills show increase at the low category or it can also be said it does not show any increase. Therefore, modification by combining more than one learning model can be used to improve students' critical thinking skills better.

\section{DAFTAR PUSTAKA}

1. Sutrisno. (2006). Fisika dan Pembelajarannya. Jurusan Pendidikan Fisika Fakultas Pendidikan dan Ilmu Pengetahuan Alam. Bandung: UPI.

2. Hartati. (2010). Pengembangan Alat Peraga Gaya Gesek Untuk Meningkatkan Keterampilan Berpikir Kritis Siswa SMA. Jurnal Pendidikan Fisika Indonesia 6. pp. 128-132.

3. Susilo. (2012). Pengembangan Model Pembelajaran IPA Berbasis Masalah Untuk Meningkatkan Motivasi Belajar dan Berpikir Kritis Siswa SMP. Journal of Primary Educational JPE 1. pp. 57-63.

4. Wilujeng, I. A., Setiawan \& Liliasari. (2010). Kompetensi IPA Terintegrasi Melalui Pendekatan Keterampilan Proses Mahasiswa S-1 Pendidikan IPA. Jurnal Cakrawala Pendidikan November Th. XXIX No. 3.

5. Wahyudin, Sutikno, \& Isa, A. (2010). Keefektifan Pembelajaran Berbantuan Multimedia Menggunakan Metode Inkuiri Terbimbing Multimedia Menggunakan Metode Inkuiri Terbimbing Untuk Meningkatkan Minat dan Pemahaman Siswa. Jurnal Pendidikan Fisika Indonesia 6. pp. 58-62.

6. Sugiyono. (2012). Metodologi Penelitian Pendidikan: Pendekatan Kualitatif, Kuantitatif, $R \& D$. Bandung: Alfabeta. 
7. Sanjaya, W. (2011). Strategi Pembelajaran Berorientasi Standar Proses Sains Pendidikan. Kencana: Jakarta.

8. Beyer, B. K. (1995). Critical Thinking. Bloomington, IN: Phi Delta Kappa Educational Foundation.

9. Ennis, R. H. (1991). An Elaboration of Cardinal Goal of Science Instruction. Educational Phylosophy and Theory.

10. Yuliati, D. I., Yulianti, D. \& Khanafiyah, S. (2011). Pembelajaran Fisika Berbasis Hand On Activities Untuk Menumbuhkan Kemampuan Bepikir Kritis dan Meningkatkan Hasil Belajar Siswa SMP. Jurnal Pendidikan Fisika Indonesia 7. pp. 23-27.

11. Triwiyono. (2011). Program Pembelajaran Fisika Menggunakan Metode Eksperimen Terbimbing Untuk Meningkatkan Keterampilan Berpikir Kritis. Jurnal Pendidikan Fisika Indonesia. 7. pp. 80-83.

12. Ningsih, S. M., Bambang, S. \& Sopyan, A. (2012). Implementasi Model Pembelajaran Process Oriented Guided Inquiry Learning (POGIL) Untuk Meningkatkan Kemampuan Berpikir Kritis Siswa. Unnes Physics Education Journal UPEJ 1 (2), pp. 44-52.

13. Akhyani, A. (2008). Model Pembelajaran Kesetimbangan Kimia Berbasis Inkuiri Laboratorium Untuk Meningkatkan Penguasaan Konsep dan Keterampilan Berpikir Kritis Siswa SMA. Jurnal Penelitian Pendidikan IPA. 2 (1). 2008, pp. 99-110.

14. Fakhriyah, F. (2014). Penerapan Problem Based Leraning Dalam Upaya Mengembangkan Kemampuan Berpikir Kritis Mahasiswa. Jurnal Pendidikan IPA Indonesia JPII 3 (1). pp.95-101.

15. Dwijananti, P \& Yulianti, D. (2010). Pengembangan Kemampuan Berpikir Kritis Mahasiswa Melalui Pembelajaran Problem Based Instruction Pada Mata Kuliah Fisika Lingkungan. Jurnal Pendidikan Fisika Indonesia 6. pp. 108-114.

16. Ihsan, M. S., Ramdani, A., \& Hadisaputra, S. (2019). Efektivitas Model Blended Learning Dalam Pembelajaran Kimia Untuk Meningkatkan Kemampuan Berpikir Kritis Peserta Didik. Jurnal Pijar Mipa, 14(2). 84-87 